\title{
The Academic Rationality and Parasitism of Literary Theory Under the Strategy of Anti-Essentialism
}

\author{
Yu Su \\ Xi'an university school of literature, Xi'an 710065, China \\ suyoo_1013@163.com
}

\begin{abstract}
As the root of literary theory, the essence of literature has always been regarded as the core and cornerstone of literary theory, and it is also the primary problem that every researcher of literary theory cannot avoid. Only by clarifying the essence of literature can we start from its basic nature and explore all aspects of literature. This paper discusses the academic rationality and parasitism of literary theory from the perspective of anti essentialism. Firstly, the paper discusses the transformation from literary theory to cultural research, and then focuses on the parasitism of literary theory. The parasitic nature of multi-disciplinary and multi doctrine makes literary theory open and pluralistic, and makes it a battlefield full of contradictions, conflicts and controversies.
\end{abstract}

Keywords: Anti essentialism, Literary theory, Academic reason, Parasitism.

\section{Introduction}

As the root of literary theory, the essence of literature has always been regarded as the core and cornerstone of literary theory, and it is also the primary problem that every researcher of literary theory cannot avoid. Only by clarifying the essence of literature can we start from its basic nature and explore all aspects of literature [1]. In different historical periods, the research on the essence of literature has never stopped. Many Chinese and foreign scholars have compiled many monographs on literary theory, and they have interpreted the essence of literature from different perspectives. The problem of literary essence is not only the meta problem of literary theory, but also the embodiment of literary concept in an era [2-3]. In different periods of literary history, the connotation of literary essence will also change. Therefore, every time we ask about the essence of literature, we will deepen our understanding of literature and make literature research more comprehensive and scientific [4].

The parasitism of literary theory is a topic that has not been seriously discussed so far. It is also a topic or scandal that literary theorists keep secret. Parasitism is not the scarlet letter on the forehead of literary theory, perhaps it is its glory. Is it a sign of openness? The main reason why literary theory is parasitic in theory is that the object of literary theory is both comprehensive and divisible in existence [5-6]. Needless to say, the object of literary theory is literature. In the state of existence, literature has both metaphysical level and empirical level, both religious level and secular level. To say it is comprehensive means that these levels are often intertwined; to say it is divisible means that different levels can be thought abstractly in theory [7]. It is worth noting that literary theory is parasitic, not that it is doomed to be locked in its parasitic theory, because it has never been parasitic on the only discipline or doctrine, and no discipline and doctrine can monopolize its parasitic nature. The parasitic nature of multi-disciplinary makes literary theory open and pluralistic, and makes it a battlefield full of contradictions, conflicts and controversies.

\section{The Transformation from Literary Theory to Cultural Research}

Anti essentialism in Chinese context is a political concept in the sense of cultural research. To state this, we can well examine the development and change of anti essentialism from literary theory to cultural research. The transformation from literary theory to cultural research is shown in Figure 1. 


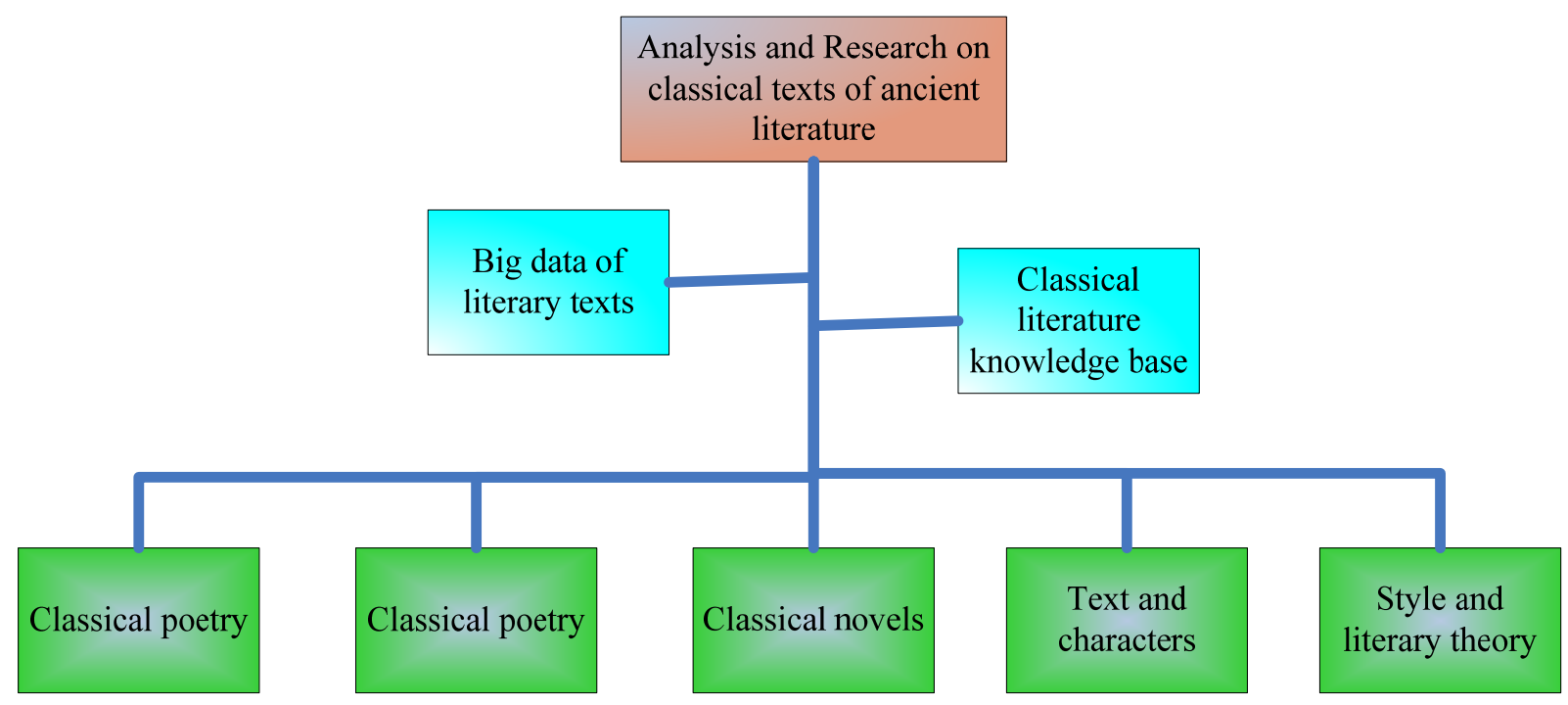

Figure 1. A sketch from literary theory to cultural research

If we stick to the essential concept framework of literary aesthetic self-discipline, it is easy to be misunderstood that "anti essentialism" and other issues have no essence of literature, or even to be understood as negation to make basic induction and summary of existing literary phenomena. Because the two attributes of "aesthetic" and "ideology" elaborated by China at present seem to have made the understanding of literature clear. From the perspective of the ideas of the book "literary theory" written by American theorists Wellek and Warren [8]. Of course, literary theory can't be equated with literary history and literary criticism. Compared with the latter two, Wellek emphasized that "literary theory is the study of literary principles, categories and standards". Although people often use the word literary criticism to summarize literary theory, "criticism must be aimed at obtaining systematic knowledge of literature and establishing literary theory at the end". From this point of view, the significance of anti essentialism to literary theory seems to be to deconstruct what Wellek said, "we must return to the task of establishing a literary theory, a set of principle system and a value theory" [9]. As Wellek once said, "literary theory is not directly related to value judgment. I think that's totally wrong. " It can be seen that the construction of Wellek's literary theory is to establish a basic principle of literary cognition, a set of value system of judging good literature and bad literature. To some extent, this is the "essentialism" knowledge construction recognized by postmodernists and anti essentialists. Because one of the fundamental principles of anti essentialism is to advocate "pluralism" and oppose monism, although unconditional pluralism is not indisputable. But the construction of literary theory represented by Wellek goes out of the above-mentioned "essentialism" on another level, because of its so-called "perspectivism" theory. When examining the essential question of "what is literature" in Wellek and Warren's literary theory, it is not logically deduced by a set of transcendental concepts higher than the existence practice of literary works, but closely based on the existing basic practical literary works in history. This makes its theoretical construction deviate from the western poetic tradition and the "philosophized" literary essence under the poet's philosophy concept, which is certainly the "philosophized" in the narrow sense [10]. The theory of "perspectivism" of Wellek and Warren leads to such a dialectic, that is, the recognition of literature.

"There is a structural nature, which has remained unchanged for many centuries. But this' structure 'is dynamic: it changes in the course of history through the minds of readers, critics and artists of its time. In this way, the standard system is constantly growing and changing, and in a sense, it can never be fully realized. But this dynamic view doesn't mean that it's just subjectivism and relativism. On the one hand, Wellek and Warren think that the essence of literature or poetry is its "decisive structure" [11]. On the other hand, they point out that the "dynamic" nature of this structure is constantly recognized and generated in history. Therefore, Wei and wo emphasized that we should use the method of "perspectivism" to integrate this standard, that is, to deal with "one" and "many". The relationship between "change" and "unchangeable" seeks the unchangeable certainty in the 
relative, and its development and change can be seen in the certainty. In this way, we can fight against both absolutism and relativism.

However, no matter how different his literary theory is, the knowledge construction of his literary theory, which is based on the theory of "New Criticism", will inevitably move to the position of "essentialism" derived from logic. In the late 1960s, French deconstruction, knowledge sociology and other theories rose. The so-called "set of principles and values" of Wellek was irretrievably damaged and disintegrated. In the era of theory or cultural theory, "anti essentialism" can be said to be popular in many aspects, and even invincible [12]. The distinction between the theory of literature and the theory of literature is of great significance. The former refers to Wellek's "generally understood as a branch of general literature or comparative literature: it aims to reflect on the conditions of literature. And the conditions of literary criticism and literary history; it is criticism or meta criticism of criticism, while the latter refers to "criticism of ideology itself, including criticism of ideology of a certain" theory of literature ". This just confirms the collapse of some big theories and the prevalence of many individual, local and historical small theories. This change is consistent with the purport of anti essentialism in the theoretical field.Anti essentialism "brings important enlightenment to literary theory, as shown in Table 1.

Table 1. Anti essentialism brings important enlightenment to literary theory

\begin{tabular}{|c|c|}
\hline & Anti essentialism brings important enlightenment to literary theory \\
\hline 1 & Anti essentialism provides a new way of thinking for the development of literary theory. \\
\hline 2 & Anti essentialism provides a new way to explain the essence of literature. \\
\hline 3 & $\begin{array}{r}\text { Anti essentialism has aroused profound reflection in the field of literary theory, which is } \\
\text { conducive to the formation of the critical spirit of dialectical rationality. }\end{array}$ \\
\hline
\end{tabular}

In today's so-called global literary research perspective, the aestheticization of daily life and the aestheticization of daily life promote the rise of life aesthetics, while Kant's aesthetics represented by pure aesthetic interest seems to be approaching dusk. The expansion of literary theory research seems inevitable. Whether it is the research object or the concept of method, the literary research method based on the close reading of the text has been greatly challenged. The essence of literature has become fluid and difficult to grasp in the process of returning to history. As a reflection of knowledge sociology in the broad sense of cultural research, it has defeated any pure belief about the essence of literature. We must face the history directly, and we can't weave all kinds of academic myths in disguise in the era of no God. Behind the literary essence of pure aesthetics and non utility lies many motives of social change with clear purpose and prominent politics. All the profound changes described above show the theoretical enlightenment of "anti essentialism" in ideology. Whether it is the misunderstanding in the framework of the above-mentioned literary theory (that literature has no essence) or the variation in cultural research (such as the "constructivism" emphasized by Tao Dongfeng after distinguishing two kinds of "anti essentialism", the subversion and constructiveness shown by "anti essentialism" coexist. Now when we reflect on the advantages and disadvantages of "anti essentialism" in the field of Chinese Literary Theory - as a conclusion - I think we can think about it in the following four aspects.

\section{The Parasitism of Literary Theory}

The parasitism of literary theory is not only an old phenomenon but also a modern one. It is not only a western phenomenon, but also a native phenomenon. Plato's poetics is parasitic on his rationalism, Aristotle's poetics is parasitic on his entity theory, Kant's art theory is parasitic on his beauty theory, and Hegel's art theory is parasitic on his absolute spirit theory. Marxist theory of literature and art is parasitic on its historical materialism, Ingarden's theory of works is parasitic on the intentional theory of phenomenology, Heidegger's theory of poetry is parasitic on his ontology, 
and Roland Barthes's theory of literature is parasitic on structural linguistics. Freud's literary criticism is parasitic on his psychoanalytic theory, feminist criticism is parasitic on Foucault's power theory, and Liu Xie's literary theory is parasitic on Tao theory.

The parasitism of literary theory means that its discourse tools and logic (or Frey's so-called "conceptual framework") are provided by its parasitism. Taking Plato's Poetics and Liu Xie's literary theory as examples, we know that "imitation" is the core concept of Plato's poetics, but it is not the special concept of Plato's poetics, but the philosophical concept he used to discuss all empirical phenomena. For Plato, not only poetry is imitation, but also all individual things. Only poetry is imitation of individual things, and individual things are imitation of reason. In the philosophical conception of imitation, poetry is the lowest imitation, that is to say, the imitation of Neo Confucianism. Therefore, poetry is the furthest from the truth (Neo Confucianism) and the least authentic. In Plato's kingdom of philosophy, as the real reason is both the basis of existence and the basis of good, so it is not only useless (unable to provide truth) but also harmful (unable to establish justice) to stay away from the real poetry. Obviously, without Plato's philosophy, there is no Plato's poetics.

Because of this kind of parasitism, the crisis and conflict of literary theory mostly come from the outside, not from the inside. We know that the fatal challenge of Plato's poetics comes from Aristotle, and the fundamental difference between Aristotle's Poetics and Plato's poetics is philosophical. Both Aristotle and Plato use the philosophical words "imitation", "general" and "individual" to talk about poetry, but Plato determines the conceptual connotation of these words in the overall framework of "rationalism", while Aristotle determines the conceptual connotation of these words in the overall framework of "substantialism", which leads to the fundamental differences between them. In Plato's opinion, as the highest, the rational form is generally independent of any other, and any individual is only an incomplete copy of the rational form. Thus, there is a conclusion that "poetry as imitation is far from the truth". In Aristotle's view, there is no real existence in Plato's rational form. Any entity is the unity of individual and general, or any general existence is related to individual. Therefore, there is a conclusion that "poetry can show the general through individual, and poetry has truth".

The theoretical conflicts, both inside and outside the doctrine, are the basic ways to produce literary theoretical knowledge and to expand its theoretical space. It should be noted that conflicts within the doctrine are compatible, while those outside the doctrine are incompatible. For example, Plato's Poetics and Aristotle's poetics are compatible in the basic principles of rationalism. Their conflicts and differences only open up the understanding of rationalism to poetry from different perspectives. In the kingdom of rationalism, we can also see the differences of Kant, Hegel, Coleridge and so on. Their differences are also the internal contradictions of rationalism. This kind of conflict does not negate their common beliefs and the most fundamental theoretical starting point and logic, but rather opens up a variety of possibilities of the same theoretical starting point and logic. Therefore, it is a concrete way for literary theory to expand itself within the doctrine. In addition to rationalism, historicism, structuralism and other internal conflicts are the same. The conflict outside of Marxism is different from this. This kind of conflict is incompatible, such as the conflict between Nietzsche's poetics, Marxist poetics, cultural research poetics and rationalism poetics. Of course, Nietzsche's poetics, Marxist poetics and cultural research poetics are also very different from each other, but they can coexist peacefully in the one-dimensional belief of historicism. The conflict between them is the conflict within the doctrine, while the conflict between them and rationalist poetics is irreconcilable. The irreconcilable nature of the conflict outside the doctrine is not a bad thing. It is this irreconcilable nature that reveals the limits and insights of the opposite sides. For example, the conflict between rationalism and Historicism reveals the former's blindness to the irrational facts of the historical movement, and the latter's blindness to the rationality beyond the historical facts, while the blindness of each other conceals their insights. 


\section{Conclusion}

Based on the parasitism of literary theory, we discuss the theoretical mechanism of knowledge production and rational formation of literary theory. In the debate of literary theory, no matter what the realistic historical motivation and personal will of the debaters are, they must have a dialogue and debate on some theoretical or theoretical logic, such as the debate on "realism", "Popularization", "authenticity", "aesthetic ideology" and so on in the history of modern Chinese literary theory. The social and historical factors of these controversies will change or disappear, while their Marxist, liberal, rationalistic and historicist logic will remain relatively stable for a long time. It is the opposite logic that prepares the way for the historical debate and reincarnation, unless the logic itself is changed. Therefore, the knowledge production and innovation of literary theory is fundamentally theoretical rather than historical. If we do not separate various historical factors and entangle them in history, there will be no hope for the change of the theory itself.

\section{References}

[1]. Miloš Milutinović, Labus, A. ,Vukaš in Stojiljković, Zorica Bogdanović, \& Marijana DespotovićZrakić. (2013). Designing a mobile language learning system based on lightweight learning objects. Multimedia Tools and Applications, vol. 74, no. 3, pp. 903-935.

[2]. Baler, P. (2014). Tiny surrealism: salvador dalí and the aesthetics of the small by roger rothman (review). Hispania, vol. 97, no. 2, pp. 579-581.

[3]. Nickel, J. W. (2013). Inherent human rights: philosophical roots of the universal declaration by johannes morsink (review). Human Rights Quarterly, vol. 35, no. 2, pp. 528-531.

[4]. Blumenthal, R. A. (2015). Margaret fuller's medical transcendentalism. Esq A Journal of the American Renaissance, vol. 61, no. 4, pp. 553-595.

[5]. Tahko, T. E. (2015). Natural kind essentialism revisited. Mind, vol. 124, no. 495, pp. 795-822.

[6]. Kelly, J. F. (2016). Zölibat in der frühen kirche: die anfänge einer enthaltsamkeitspflicht für kleriker in ost und west by stefan heid. Catholic Historical Review, vol. 84, no. 3, pp. 523-524.

[7]. Wang, D. W. (2016). Chinese literary thought in modern times: shi, xing, and shishi. Journal of Chinese Literature and Culture, vol. 3, no. 2, pp. 258-288.

[8]. Julián Jiménez Heffernan. (2015). The sovereign and the saint: francisco ayala's critique of the baroque in context. Revista Hispánica Moderna, vol. 68, no. 1, pp. 1-19.

[9]. Tsika, N. A. (2016). Pink 2.0: encoding queer cinema on the internet. Qed A Journal in Glbtq Worldmaking, vol. 3, no. 1, pp. 157-159.

[10]. Baker, T. C. (2017). Harmonic monads: reading contemporary scottish fiction through the enlightenment. Scottish Literary Review, vol. 9, no. 1, pp. 95-113.

[11]. Fogleman, A. (2017). In defense of common sense: lorenzo valla's humanist critique of scholastic philosophy by lodi nauta. Comitatus A Journal of Medieval \& Renaissance Studies, vol. 41, no. 1, pp. 279-281.

[12]. Karunanayake, D. (2016). Keywords for asian american studies ed. by cathy j. schlund-vials, linda trinh võ, k. scott wong. Journal of Asian American Studies, vol. 19, no. 2, pp. 267-270.

[13]. Blumenthal, R. A. (2015). Margaret fuller's medical transcendentalism. Esq A Journal of the American Renaissance, vol. 61, no. 4, pp. 553-595. 